\title{
Fluvial Landscape and Land Utilization in Dentam Khola Basin - A Case Study of Sikkim Himalaya
}

\author{
Dr. Bedhas Ujjwal Mandal \\ Assistant Professor \\ Department of Geography \\ Shyampur Siddheswari Mahavidyalaya, Howrah, WB, India
}

\begin{abstract}
The main thrust of present paper is fluvial landscape and related land utilization patterns, problems, management of a micro basin of Sikkim Himalaya, namely Dentam Khola basin, situated in the western part of the Sikkim state of India. Hence, it is a micro level geo-scientific analysis of land utilization and related problems on a mountainous terrain influenced by both tectonic and fluvial activities and related land use planning through proper land use development with technological advancement and human interferences. This basin represents an ample scope to study the landforms and processes related to existing fluvial landscape which influence the distribution of land resources, land uses and their problems depending on topographic variation, soil fertility and others. Proper land use planning and development strategies should be adopted for the socio-economic betterment by technological advancement specially in agriculture maintaining the ecological sustainability in this Sikkim Himalayan mountainous terrain.
\end{abstract}

Keywords: Fluvial landforms, terrain, land potentiality, land use management.

\section{Area and Location}

The Dentam Khola basin can be designated as a micro level hydro-geomorphic unit covering an area of 60 sq.km extending from $27^{\circ} 12^{\prime} \mathrm{N}$ to $27^{\circ} 16^{\prime} \mathrm{N}$ and $88^{\circ} 9^{\prime} \mathrm{E}$ to $88^{\circ}$ $10^{\prime} \mathrm{E}$. From the administrative viewpoint, this basin falls under the Gyalshing sub-division of West District, Sikkim (India). Physiographically, it is included as an important sub-basin under Rangit basin. (Plate No.1)

\section{Drainage}

Dentam Khola is the major perennial river of the basin under study. Actually the two small streams meets in the south-central portion of Mangmo revenue block, Gyalshing sub-division at an altitude of $2200 \mathrm{~m}$ approximately and the combined flow of water named as Dentam Khola and directs towards the northern portion to meet Kalej Khola. There are numerous tributaries of Dentam Khola, flowing from the northern ridge to southern low elevated land, are mostly non-perennial or rain-fed in character.

\section{Fluvial Process}

With regard to the prevailing geomorphic process, particularly exogenetic concerning climate- vegetation-soil complex, a general discussion should be done to analyze the development of fluvial landforms which is 'the function of structure, process and stage' (W.M.Davis).

In case of Dentam Khola, the river performs mainly the erosional activities. It erodes its sides and beds, transport the eroded materials such as rock particles, sand along its course. DentamKhola degrades the surface of the terrain, carves its valley, and creates various erosional landforms. Like other streams, erosion is the most important from fluvial process from the view point of landscape evolution of the basin located in mountainous terrain of West Sikkim. The factors controlling the erosional process of
Dentam Khola includes channel, volume of water, channel velocity, water discharge, load etc. Erosion becomes maximum on the high moderate slope, highly rugged terrain of the southern part. Here, the river frequently forms the cascade, rapid like landforms through the narrow $\mathrm{V}$-shaped channel. The erosion becomes minimum at present, beside the Dentam valley and near the confluence with the larger river, Kalej Khola. Here the river deposits the transported bed loads along its slight wider channel. (Figure No.2)

\section{Terrain Condition}

As a potential control of climatic variation as important as the litho-tectonic structural variation of Dentam Khola basin, it is associated with relief and active morphogenesis development of 2-tier terrace system of the basin. Terrain is the outer expression of underground structural control which helps to study the landforms development adopting advanced techniques concerning a methodological approach.

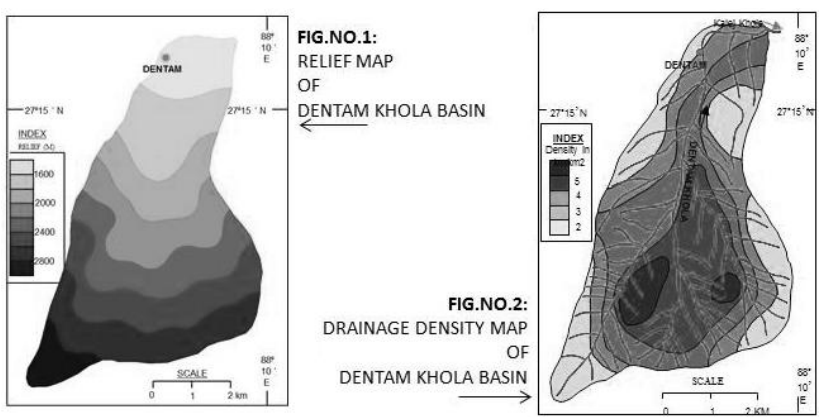

The relief map expresses the gradual increasing rate of relief which is highest in the south-western corner with narrow contour spacing and towards north; it is widely spaced indicating the gradual decreasing of altitude near Dentam. (Figure No. 1). 


\section{International Journal of Science and Research (IJSR) \\ ISSN (Online): 2319-7064}

Index Copernicus Value (2013): 6.14 | Impact Factor (2015): 6.391

Drainage density and average slope mainly show the density of drainage and variation slope in degree respectively. Both are essential in study, though they are positively related. The highest value of drainage density above $5 \mathrm{~km} / \mathrm{sq} . \mathrm{km}$. which is found in the central part and the minimum value is below $2 \mathrm{~km} / \mathrm{sq} . \mathrm{km}$.(Figure No.2). The average slope map shows that highest degree of slope are scattered in four areas ranging above $70^{\circ}$ and the minimum slope is near the confluence with larger stream where tectonic valleys have developed ranging below $35^{\circ}$.

Through the detail field work, long profile has been prepared with the help of toposheet (1970) in two phases. One is $100 \mathrm{~m}$ upstream from Dentam Bridge, near Sangkhu and another is $100 \mathrm{~m}$ downstream from Dentam. Both profiles have shown the gradual decrease of amplitude with the presence of several breaks of slopes. Two cross profiles have also been prepared in one point of break of slope from each long profile. They indicate the channel pattern and thalweg position which is upper in the upper cross profile and low in the lower part cross profile.

Following Horton's method of stream order, Dentam Khola is $4^{\text {th }}$ order stream indicating the homogeneous rock character, but strongly affected by faulting and typical folded structure.

\section{Major Fluvial Landforms}

Terrain analysis also influences the development of landforms. The major fluvial landforms of Dentam Khola basin are as following: (Plate No. 2)

i. Interlocking spur - This typical fluvial feature is found to be developed on rugged terrain of southern part of the sub basin.

ii. Waterfalls -Here, waterfalls are generally found as cascades and cataracts along Dentam Khola in upper and middle portions of the sub basin.

iii. V-shaped valley- The valley in the upper part of basin has been formed as narrow $\mathrm{V}$-shaped, having steep convex valley side slopes. It is the result of accelerated rate of down cutting or vertical erosion. The valley shape becomes wider towards its confluence area beside the apex part of Dentam valley, having moderate and steep both types of valley side slopes.

iv. Fluvial terrace- This is one of the significant landforms of fluvial action. They are arranged in step like forms along both side of the river. They are found here as unpaired terrace indicating tectonic activities. Dentam valley is the best example of such type of terrace. It was originally developed by fluvial process, but the neotectonic activity of the later stage pushed it up to the present altitude. Here, actually the alluvial terrace transformed into tectonic terrace with time. Besides.

v. Knick point- near Sangkhu village.vii. Pot hole- along Rocky River bed viii. Straight channel-are found.

\section{Major Land Utilizations}

To discuss the aforesaid topic in the background of proper management procedures of land utilization of Dentam Khola basin, the concept of land units is a very important parameter. Generally four types of land units are found in this Eastern Himalayan mountainous terrain of Sikkim.

1. Agricultural Land on Mountainous Terrain

2. Settlement Area on Mountainous Terrain and Slope

3. Forest Land

4. Grazing Land on Mountainous Slope

5. Glaciated Area or Waste Land.

\section{Land Use Development}

The term 'biotic state' applied for Sikkim state, is perfectly represented by the Dentam Khola basin, West Sikkim. Green forest cover across the lofty mountain and ridges is the major land resource covering almost $60 \%$ of the land cover of the basin. The rugged terrain is covered by moderate to dense deciduous and coniferous forest covers from low to moderate altitude river valleys and along the moderate to high mountainous slopes, especially of the western part and high ridges of the northern and southern marginal parts of this basin.

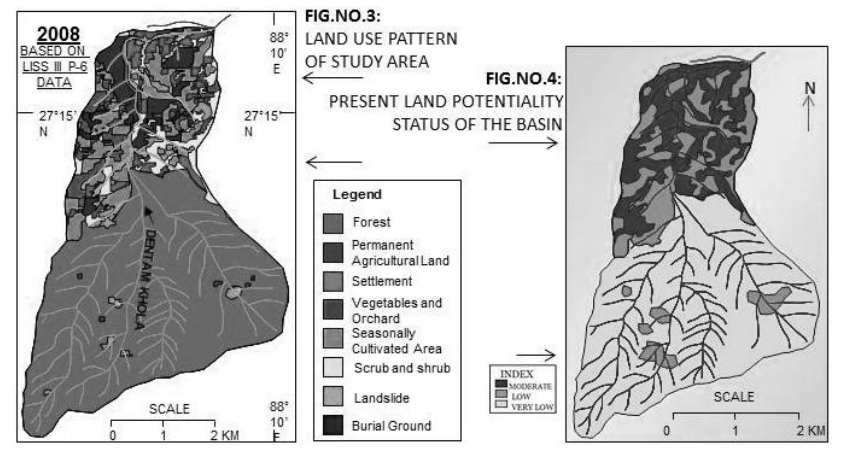

Above $50 \%$ of the area of the basin falls under forest land, in the form of Reserved Forests, Wild life Sanctuaries etc. are found in the vast southern and northern portion of the district except river valleys and the waste land or glaciated areas are found along the narrow western and northern margins of the study area. Here, the forest cover are found to be protected to maintain he ecological balance and natural wild life preservation in the northern, central and western parts of this region. Rhododendron sanctuary, Sungri reserve forest etc. are remarkable.

There is the major use of this forest through lumbering and collection of forest by-products and spices. Few portion of the total area $(30 \%)$ is used as arable land and settled areas, generally along the low to high terrains of the major river valleys. They are used for grain crop, vegetable cultivation. The nodal point of this basin, Dentam Bazar or Dentam village is situated in such a moderate high terrain of Dentam Khola. Rest $10 \%$ land falls under the transport and communication system. Here, a single state highway is the major medium of road transport and some power lines and telephone lines across the mountain are the major medium of communication. 


\section{International Journal of Science and Research (IJSR) ISSN (Online): 2319-7064}

Index Copernicus Value (2013): 6.14 | Impact Factor (2015): 6.391

Table 1: Decadal Change of Land Use Patterns (Year2000-2010) of Two Selected Revenue Blocks under Dentam Khola Basin

\begin{tabular}{|c|c|c|c|c|}
\hline $\begin{array}{c}\text { Revenue } \\
\text { Blocks }\end{array}$ & $\begin{array}{c}\text { Mangmo } \\
(2000)\end{array}$ & $\begin{array}{c}\text { Dentam } \\
(2000)\end{array}$ & $\begin{array}{c}\text { Mangmo } \\
(2010)\end{array}$ & $\begin{array}{c}\text { Dentam } \\
(2010)\end{array}$ \\
\hline $\begin{array}{c}\text { Total } \\
\text { Population }\end{array}$ & 686 & 451 & 732 & 512 \\
\hline $\begin{array}{c}\text { Total Area } \\
\text { (Sq. km.) }\end{array}$ & 191 & 101 & 191 & 101 \\
\hline $\begin{array}{c}\text { No. of } \\
\text { Household }\end{array}$ & 153 & 85 & 182 & 98 \\
\hline Forest & 2.56 & 0.95 & 2.41 & 0.84 \\
\hline $\begin{array}{c}\text { Irrigated } \\
\text { Land }\end{array}$ & 38.32 & 27.25 & 43.75 & 33.42 \\
\hline $\begin{array}{c}\text { Unirrigated } \\
\text { Land }\end{array}$ & 86.90 & 20.75 & 81.96 & 14.22 \\
\hline $\begin{array}{c}\text { Culturable } \\
\text { Waste }\end{array}$ & - & .32 & 0.21 & .72 \\
\hline $\begin{array}{c}\text { Fallow } \\
\text { Land }\end{array}$ & 62.73 & 49.48 & 58.38 & 45.66 \\
\hline Others & 0.49 & 2.25 & 4.29 & 6.14 \\
\hline
\end{tabular}

Source: Agricultural Department, Gangtok

The land utilization is a dynamic process which is controlled by some environmental factors in Dentam Khola sub-basin. A detail comparative study of land useland cover of Dentam Khola sub basin has been done by the worker considering two maps of 1970 and 2010 and they show that how the land utilizations have been changed between 40 years long time span. Here, two land cover and land use maps have been prepared which are based on two different sources. One has been prepared from Toposheet of 1970 and another has been prepared from LISS-III, P-6 Satellite image of 2010. These two land cover and land use maps are showing how the land uses have changed with the advancement of technology and increasing population in respect of new developmental strategies both social and economic in a sustainable manner, solving the potentiality problems of the basin. (Figure No.3)

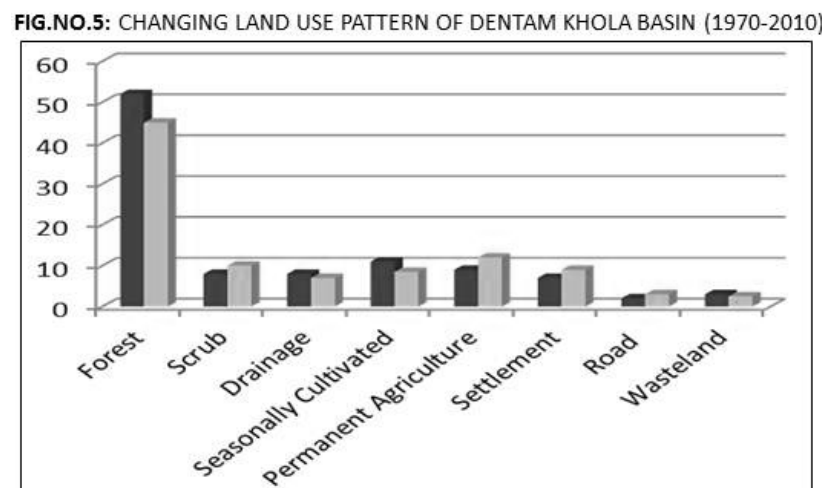

Source: Data from Toposheet and Sat. Image and Field verification

The map of the year 1970 shows the dominance of forest cover of $60 \%$ extending over the entire central and southern parts of the basin; mainly areas of ridges where from the main streams have been originated. The major land uses are shown in the following table:
Table 2: Land Use Patterns of Dentam Khola Basin (1970)

\begin{tabular}{|c|c|c|}
\hline Sl. No. & Major Land Uses & Percentage Of Area \\
\hline 1 & Forest land & 60 \\
\hline 2 & Seasonally Cultivated Land & 11 \\
\hline 3 & Permanent Agricultural Land & 9 \\
\hline 4 & Drainage & 8 \\
\hline 5 & Settlement Area & 7 \\
\hline 6 & Waste Land & 3 \\
\hline 7 & Road Construction & 2 \\
\hline
\end{tabular}

Based on Toposheet, S.O.I. 1970

The second map represents also the pre-dominance of forest cover concentrating almost the same area but it is decreased in small percentage from north to south (55\%). Through the image analysis, the numbers of parameters have increased showing different aspects of land uses which have recently developed with the help of environmental and anthropogenic impact.

Table 3: Land Use Patterns of DentamKhola Basin (2010)

\begin{tabular}{|c|c|c|}
\hline $\begin{array}{c}\text { Sl. } \\
\text { No. }\end{array}$ & Major Land Uses & $\begin{array}{c}\text { Percentage } \\
\text { of Area }\end{array}$ \\
\hline 1 & Forest land & 45 \\
\hline 2 & Permanent Agricultural Land & 12 \\
\hline 3 & Seasonally Cultivated Land & 8.5 \\
\hline 4 & Settlement and Market Area & 9 \\
\hline 5 & Scrub Land & 10 \\
\hline 6 & Drainage & 7 \\
\hline 7 & Road Construction & 3 \\
\hline 8 & Landslide & 3 \\
\hline 9 & Waste Land & 2 \\
\hline 10 & Burial ground & 0.5 \\
\hline
\end{tabular}

Based on LISS-III, P-6 Satellite Image and Field Survey 2010

The changing patterns of land use are the most vital study of Dentam Khola basin. The aforesaid comparative study of 1970 and 2010 shows the major changes of land utilizations. Regarding the climate and soil character, nature of rugged terrain play the role of controlling agent of land cover and land use. But with the advancement of science and people awareness, farmers have become to know that how morphological features like tectonic terraces and valleys can be utilized as crop fields providing suitable manure and irrigation facilities. Plantation of large cardamom has been increased with the development of agricultural plots on low moderate to high moderate slope valleys and other terrain surfaces of southern part of Dentam. With the increasing rate of population after 1990's sudden change of land uses are found which has been clearly shown through the Tables shown above.

From the above analysis of past and present land use patterns of the Dentam Khola sub-basin, it is found to be developed depending on the diversified terrain characteristics along with the variation of climate and land capability. Least land use pattern has been developed on high to moderate rugged terrain of south and central parts and various land use, especially agricultural plots have been developed on moderate to gently sloping terrain of northern part, near Dentam which is very clear in the 


\section{International Journal of Science and Research (IJSR) \\ ISSN (Online): 2319-7064}

Index Copernicus Value (2013): 6.14 | Impact Factor (2015): 6.391

transect chart, prepared from toposheet. It should be noted that with the increasing population, percentage of various land use patterns have been changed. For example, the forest cover has decreased from $52 \%$ (in 1970) to $45 \%$ (in 2010) and on the other hand, agricultural plots and settlements have expanded towards the suitable lands for each purpose with the help of modern techniques.(Figure No.5)

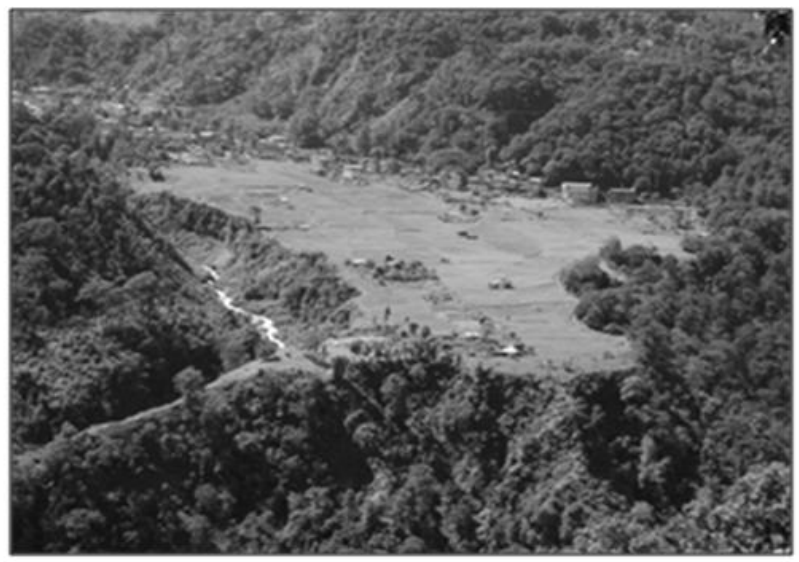

PLATE NO. 1:

PANAROMIC VIEW OF THE BASIN SHOWING DENTAM VALLEY LAND USE

\section{Agricultural Land Use}

West district has very diverse ecological conditions which on one hand prevent adoption of common crops and varieties over wide region and on the other hand favour cultivation of many kinds of fruits, vegetables both on and off seasons and also provide conductive agro-climatic situations for growing commercial crops like cardamom, ginger etc. Sikkim including West district though very small in size has great potential for growing all kinds of crops with success in the mountainous terrain. Agricultural resources mainly involve various types of crops, vegetables, fruits etc. (Plate No.3)

The crop production system is performed through three major agricultural periods. They are:

i. $\quad$ Kharif period ( May - September )

ii. Rabi period (October - February)

iii. Zaid period (March - April)

Table 4: Production of Crops (2009-2010)

\begin{tabular}{|c|c|c|}
\hline Types of Crops & Name of the Crops & Yield/Hec. in Kg. \\
\hline Cereals & $\begin{array}{c}\text { Rice, Wheat, Maize, } \\
\text { Finger millet }\end{array}$ & 1340 \\
\hline Pulses & Urd, Other Pulse & 946 \\
\hline Oil Seeds & $\begin{array}{c}\text { Rapseed, Mustard, } \\
\text { Soyabean }\end{array}$ & 810 \\
\hline Fruits & Mandarin, Other Fruits & 1050 \\
\hline Vegetables & Rabi, Kharif, Off-season & 4550 \\
\hline Spices & $\begin{array}{c}\text { Large Cardamom, } \\
\text { Turmaric, Ginger }\end{array}$ & 2800 \\
\hline Roots-Tubers & Potato, Others & 4105 \\
\hline
\end{tabular}

Source: Agricultural Department, Gangtok

\section{Major Land Use Problem}

Situated on tectonically unstable and rugged terrain of fluvial environment, Dentam Khola basin faces some major problems related to optimum land utilization. They are as following:

1. High to moderate rugged nature of the present land cover.

2. Soil profiles over the basin are mostly immature in nature.

3. Less capability of soil binding and resultant soil erosion and landslide problems.

4. Less presence of flat terrain and gently sloping terrace.

5. Improper management of land for the suitable purpose

6. Lack of multi cropping and crop rotation farming.

7. Least transport (only road transport) accessibility due to less development of transport network over the rugged surface.

8. Problems of different natural and man-made hazards like earthquake, landslide, soil erosion and accelerated soil erosion, flash flood, deforestation etc.

9. Least use of the modern agricultural techniques for the upliftment of land fertility, thus dominance of traditional, subsistence farming mostly resulting less productivity.

10. Last but not the least, lack of consciousness of local inhabitants for optimum use of land, commercialization of agricultural products, better accessibility with the major urban centers situated outside the study area and overall resultant socioeconomic backwardness.

\section{Water Resource Management and Land Utilization}

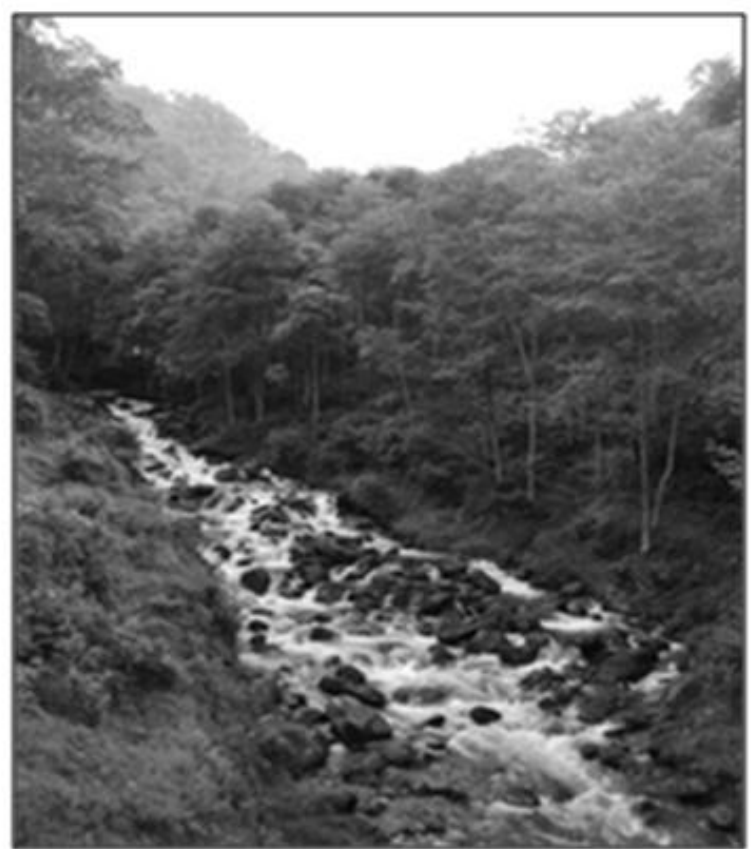

PLATE NO. 2:

DENTAM KHOLA FLOWING OVER RUGGED TERRAIN THROUGH DENSE MIXED FOREST

Volume 5 Issue 6, June 2016 www.ijsr.net 


\section{International Journal of Science and Research (IJSR) \\ ISSN (Online): 2319-7064}

Index Copernicus Value (2013): 6.14 | Impact Factor (2015): 6.391

Water resource management is another important stream of the present study which helps to get emphasis on seasonal variation of land utilization and further land use planning. The main sources of water are the perennial and semi perennial rivers (kholas) and streamlets which are termed as surface water and mainly this water is used for agriculture. During the rainy season there are abundant source of water which is supplied in step cultivated areas but the problem arise during the rabi season when the local farmers need proper and systematic irrigation for cultivating vegetables and newly developed horticulture as well as floriculture. Water can be channelized from river course to agricultural plots, especially paddy field through man madecanel. Water for domestic or daily purpose can be served by pipe line to the settlement area or market place. Conservation of water in concrete reservoir is a necessary one for better performance of the socioeconomic activities.

\section{Land Potentiality Status and Land Use Planning}

The hilly and rugged terrain of Dentamkhola basin is characterized by dense forest and minimum cultivation in strip like plots as step cultivation. The land potentiality of the entire area is marked by the varied nature of soil, drainage, slope and lithological circumstances which have enhanced the analytical aspects and classification of lands for proper land use planning. In the context of changing land use pattern and agricultural advancement of the study area, it is better to follow the distributional pattern and analysis of land potentiality. Based on the method of Storie Index (1978) of soil rating, the Dentam Khola basin shows mainly three (3) types of land potentiality grades.

Table 6: Land Potentiality status of the Study Area

\begin{tabular}{|c|c|c|l|}
\hline Grade & Nature & Rating & \multicolumn{1}{|c|}{ Land Potentiality Status } \\
\hline 3 & Fair & $40 \%-59 \%$ & $\begin{array}{l}\text { Soils have moderate quality } \\
\text { with less wide range of } \\
\text { suitability and may give } \\
\text { good result with certain } \\
\text { specialized crops. }\end{array}$ \\
\hline 4 & Poor & $20 \%-39 \%$ & $\begin{array}{l}\text { Soils have narrow range in } \\
\text { agricultural possibilities. } \\
\text { Few soils in this grade may } \\
\text { be good for rice, but not so } \\
\text { for other crops. }\end{array}$ \\
\hline 5 & $\begin{array}{l}\text { Very } \\
\text { Poor }\end{array}$ & $10 \%-19 \%$ & $\begin{array}{l}\text { Soils have very limited use } \\
\text { except for pasture because of } \\
\text { adverse conditions. }\end{array}$ \\
\hline
\end{tabular}

Based on field survey, Toposheet, Sat. Image

From the above table, grade- 5 category covers above $55 \%$ of the basin area, mainly on the southern and central high to moderate rugged terrain. The least portion of $20 \%$ falls under grade- 3 category situated on the northern moderate to gently sloping surface. This category actually helps to develop the plots for grain crop cultivation and social infrastructure like settlement, market area, metalled road transport etc. Actually, the development of economic activities along with the socio-cultural advancement are influenced significantly by the distribution of different land potentiality categories and thus helps in land use planning for the betterment of socio-economic status of the study area. (Figure No.4)

\section{Land Use Management}

The major land use management strategies which can be taken in GO, NGO level and by local inhabitants are as following:

1. Proper usage of the fluvial landforms such as, river terraces for the development of agriculture.

2. Development of agricultural land for grain crops cultivation on the flat uplifted tectonic terraces along both banks of Dentam Khola river.

3. Flattering of rugged terrain considering land potentiality and ecological balance.

4. Application of organic manures and NPK fertilizers to achieve fertility of the unused land and adaptation of proper agricultural method and crops.

5. Construction of eco-friendly barrier (wall made of rock fragments) along the plots under contour farming or terraces to protect against the loss of nutrients by soil erosion.

6. Management of irrigation facility by pipeline from nearby stream/ spring specially during Rabi phase for cultivation

7. Introduction of 'Model Village' and development of various social infrastructures including introduction of modern agricultural techniques and agricultural commercialization.

8. Construction of new metalled roads and renovation of existing roads, foot-cart tracks by Govt. and nonGovt. organizations to enhance transport connectivity with outside market area and settlements.

9. Preventing unscientific construction and optimum utilization of land for proper purpose, afforestation along hill slope help to minimize the effect of hazards like- soil erosion, landslide, flash flood etc.

10. Development of eco-tourism based on aesthetic resource or natural beauty of the study area. Dentam valley, Uttarey, HeeGaon, green forest and lofty mountain are main elements of tourist attraction. Trekking is also a rising adventure tour of the study area. E.g. Barsey - Dentam trekking route is a favourite one.

11. Last but not the least, the overall consciousness of local inhabitants, Govt. and Non-Govt. authorities for land use management by proper mitigation of land potential problems towards the sustainable socioeconomic development maintaining ecological sustainability of this Middle Himalayan terrain of Sikkim.

\section{Conclusion}

Overall, when economic and social utilities and applicability of each land use pattern and concerned land potentialities have been considered, the identification of land potential problems in each pattern and their probable mitigation strategies from macro to micro level areas of Dentam Khola basin are the necessary ones and the detail land use planning on the basis of the achieved maximum land potentialities thus can be channeled towards the socio-economic betterment and it will be more effective by mutual understanding of physical processes and human interferences. 


\section{International Journal of Science and Research (IJSR) \\ ISSN (Online): 2319-7064}

Index Copernicus Value (2013): 6.14 | Impact Factor (2015): 6.391

So, in this context comprising the environmental hazards, it is needed to better water resource management and care full measurements of contour farming through a systematic and scientific way. It can be said in conclusion that maintaining the ecological sustainability, the land use problems of the Dentam Khola basin under fluvial environment of Sikkim Himalaya can be solved through proper and optimum utilization of land resources available considering present land potentiality status and adopting scientific modern techniques for the overall socioeconomic advancement.

\section{Acknowledgement}

The present author wishes to offer his indebtedness and gratefulness to his teacher and guide Professor S. C. Mukhopadhyay, M.Sc., Ph.D., D.Sc. (Cal.), Rtd. Professor of Department of Geography, Calcutta University. He is thankful to NATMO, GSI, SOI and NBSS\&LUP and other Govt. and Non-Govt. organizations of Sikkim. He is grateful to the local people and authorities of the study area without whose kind cooperation this work would not fully possible. The author is thankful to Dr. Mery Biswas, Assistant Professor in Geography, Presidency University for her valuable criticisms, and continuous encouragement in this undertaking.

\section{References}

[1] Mukhopadhyay, S.C. 1982. The Tista Basin - A study in Fluvial Geomorphology, K.P.Bagchi and Company, Calcutta and New Delhi, pp.179-229.

[2] Valdia, K.S. 1998. Dynamic Earth, University Press (India) Ltd., pp.57-82.

[3] Geological Mapping in the Western Part of Sikkim (Progress Report for the Field Session 1965-66) September 1966. Geological Survey of India.

[4] Vink, A.P.A. 1975. Land Use in Advancing agriculture, Berlin Heidelberg New York, pp. 33-134.

[5] State Report on Agriculture Census, 1980-81, Government of Sikkim.

[6] Area and Food Production Statistics of Sikkim, 200304, Department of Food Security and Agriculture Development, Government of Sikkim.

[7] Census Book of Sikkim, Census of India, 2001.

[8] Land Utilization Statistics of Sikkim, Department of Agriculture, 1995-96. Government of Sikkim, Tadong, pp. 1-10, 170-290.

[9] Singh, Savindra, Physical Geography, 2002, Prayag Pustak Bhawan, Allahabad, pp.225-269

Volume 5 Issue 6, June 2016 www.ijsr.net 